\title{
THE HYDROPHILOUS VEGETATION OF WESTERN CRETE*
}

\author{
S. R. GRADSTEIN ${ }^{1}$ \& J. H. SMITTENBERG ${ }^{2}$ \\ Institute for Systematic Botany, Heidelberglaan 2, Utrecht, The Netherlands \\ 2 Provinciale Planologische Dienst, Postbus 115, Leeuwarden, The Netherlands
}

Keywords: Crete, Hydrophilous vegetation, Syntaxonomy

\section{Introduction}

Knowledge of Mediterranean hydrophilous vegetation is generally poor. A survey and classification of hydrophilous communities of the Mediterranean part of France is given by Braun-Blanquet et al. (1952). Zohary (1962) presents a classification of the hydrophilous vegetation types of Israel, which differs considerably from the classification of Braun-Blanquet et al. (1.c.). Unfortunately, the vegetation units distinguished by Zohary are rather insufficiently described which makes it difficult to interprete them in the light of the Braun-Blanquet classification. Salt-marshes of the eastern Mediterranean region have been subjects of phytosociological studies by Oberdorfer (1952), Lavrentiades (1964) and Wolff (1968).

The island of Crete has been included in the general descriptive and very informative work of Rechinger (1951) on the phytogeography of the Aegean region. The first phytosociological account on the vegetation of Crete, together with a useful vegetation map of the island, was published recently by Zohary \& Orshan (1966). These authors presented a treatment of the classes Quercetea ilicis and Aceretea orientalis. Other classes mentioned by these authors to occur on the island are the Euphorbietea dendroides, Astragaletea cretici, Ammophiletea arenariae, Rudereto-Secalinetea, Salicornietea and the hydrophilous

* Nomenclature of vascular plants follows Flora Europaea (1964-1972) and, for taxa not yet treated, Greuter (1973) or Rechinger (1943). Bryophyte nomenclature follows Gams (1957).

** Thanks are due to Dr. J. van Donselaar, Rijksplanologische Dienst, The Hague, for critically reading the manuscript, and to Dr. W. Greuter, Conservatoire et Jardins Botaniques, Geneva, for checking the identification of part of our collections of vascular plants (Greuter 1973).
Populetea and Phragmitetea. No observations were published on the latter two classes.*

This paper, which is a condensed and fully revised version of a previously published mimeographed report (Gradstein \& Smittenberg 1968), presents a phytosociological account of the hydrophilous vegetation of the western part of the island of Crete: districts Apokoronos, Khidonia, Kissamos, Selinos and Sfakia (Fig. 1). The communities treated belong to the phytosociological classes Potametea, Adiantetea, Phragmitetea, Juncetea maritimi, Molinio-Juncetea, Isoeto-Nanojuncetea and AlnoPopuletea. Data were obtained during a 1.5 month stay on the island in 1967, 9 April-16 May.

\section{Methods}

The vegetation was studied according to the BraunBlanquet approach (Ellenberg 1956, Braun-Blanquet 1964). Abundance and coverage of each species was measured by means of the Braun-Blanquet scale, and occasionally by means of a simplified Tansley (1946) scale: $d$ (dominant), c (codominant), $f$ (frequent), $r$ (rare).

The system of plant communities in southern France by Braun-Blanquet et al. (1952) served as a basis for syntaxonomical classification. Due to the fact that hydrophilous communities, like hydrophytes, often have a more or less pluriregional distribution, we could compare our data also with the much more advanced classification of western European hydrophilous communities by Westhoff \& Den Held (1969), especially for higher units.

* After completion of the manuscript we received Dr. Greuter's account on the geobotany of the island: "Die Insel Kreta - eine geobotanische Skizze" (Veröff. geobot. Inst. Zürich 55: 141-197, 1975). This important work does not contain new data on hydrophilous communities. 
To delimit our vegetation units we have used regional characteristic taxa or combinations of taxa. The term "regional characteristic" is used here in a very general way, indicating that a certain taxon or combination of taxa was found to differentiate a particular vegetation unit on Crete. We believe that our data are not sufficient for distinguishing the traditional Braun-Blanquetian categories of character- and differential taxa. The distinguished vegetation units are called associations if they match with associations described elsewhere. New associations are described only when records are available from more than one locality in the investigated area. Apparently undescribed vegetation units observed in only one locality are called communities.

The same term is applied to units of uncertain affinity within the hierarchic system. In some cases variants are distinguished within associations or communities.

\section{Short description of the island}

The island of Crete is ca. $245 \mathrm{~km}$ long and 12 to $52 \mathrm{~km}$ wide. It is the largest island in the eastern Mediterranean.
The island is situated at ca. $35^{\circ}$ N.Lat. A short account on geology, soils and climate was given by Zohary $\&$ Orshan (1966), from which source some pertinent data are presented here.

The island is dominated by four mountain ranges. The largest are the Levka Ori in the western part of the island, with peaks up to $2400 \mathrm{~m}$. The mountains generally consist of hard limestones which are porous and often karstic. Other types of rock occur locally, e.g. schists made up of metamorphic triassic rock, which are particularly widespread in the lower mountains of the western part of the island.

\begin{tabular}{l|c|c|c|c}
\hline \multirow{2}{*}{ town } & \multirow{2}{*}{ alt. } & \multicolumn{2}{|c|}{ mean temperature } & $\begin{array}{c}\text { mean annual } \\
\text { precipitation }\end{array}$ \\
\cline { 3 - 5 } & & Jan. & Aug. & $\pm 600 \mathrm{~mm}$ \\
\hline Hania & $0 \mathrm{~m}$ & $11,3^{\circ} \mathrm{C}$. & $25,7^{\circ} \mathrm{C}$. & $\pm 425 \mathrm{~mm}$ \\
Iraklio & $0 \mathrm{~m}$ & $12,2^{\circ} \mathrm{C}$. & $26,5^{\circ} \mathrm{C}$. & \pm \\
Sitia & $0 \mathrm{~m}$ & $?$ & $?$ & $\pm 350 \mathrm{~mm}$ \\
\hline
\end{tabular}

Fig. 2. Mean temperature and precipitation in Hania (W. Crete), Iraklio (C. Crete) and Sitia (E. Crete). After Zohary and Orshan 1966 (slightly modified).

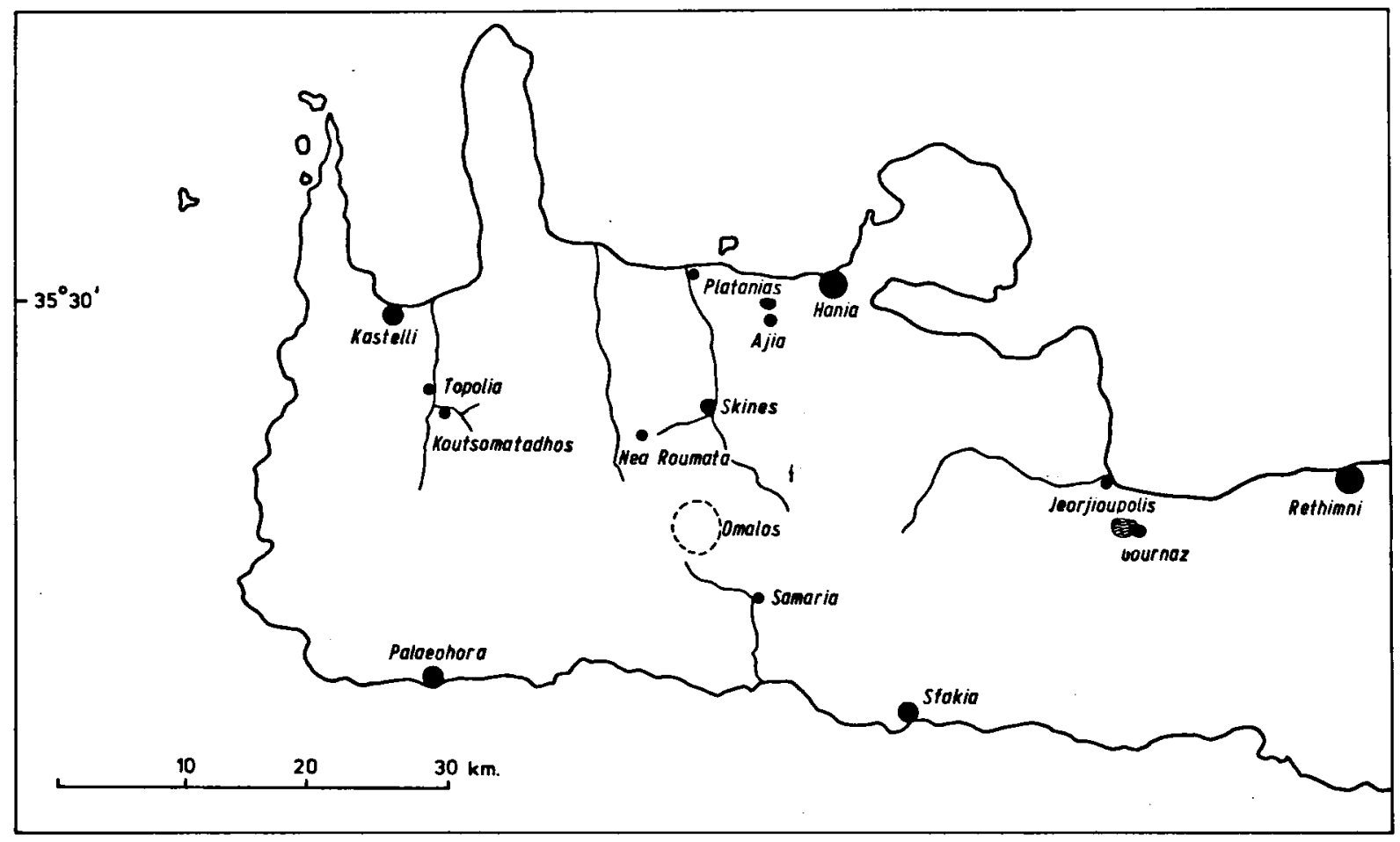

Fig. 1. Map of Western Crete, showing the localities of investigation. 
Crete has a Mediterranean climate with a mean annual temperature of $19^{\circ} \mathrm{C}$ in the lowlands. Frost and snowfall are rare at sea level, but above $1500 \mathrm{~m}$ snow can still be seen in May. Precipitation is restricted mainly to the period from late autumn to early spring. It is much higher in the western than in the southern and eastern parts of the island (Fig. 2).

Variation in precipitation may occur over relatively short distances in connection with altitudinal variation. In the relatively humid province of Hania precipitation varies from $1045 \mathrm{~mm}$ in the mountains at $800 \mathrm{~m}$, to $425 \mathrm{~mm}$ along the southwest coast. The mean annual rainfall and the nature of the substrate largely determine the waterregime of a site and the possible development of hydrophilous vegetation. High annual precipitation and the presence of fairly large areas of well-irrigated schistose substrates in the western part of the island favour the development of hydrophilous vegetations in that region.

\section{Localities (Fig. 1)}

\section{Jeorjioupolis (district Apokoronos)}

A variety of brackish vegetation types is found in the narrow coastal belt at the village of Jeorjioupolis, due to the presence of numerous brackish springs and rivulets. Vegetation types observed here are: Scirpetum maritimi et litoralis and Juncetum subulato-maritimi (both common), Cyperus distachyus-Apium nodiflorum comm., Schoenus nigricans-Centaurium pulchellum comm. and Festuca arundinacea-Elytrigia elongata comm.

\section{Platanias (district Khidonia)}

At the North coast near Platanias, hydrophilous vegetation is found along the mouth of the river Keritis. Vegetation types studied in this area are: Scirpetum maritimi et litoralis, Apietum nodiflori, Dorycnio-Caricetum otrubae and, on steep banks, the Equisetum telmateia-Arundo donax comm. Monospecific aquatic vegetation types of Potamogeton fluitans, Zannichellia palustris ssp. palustris, Ceratophyllum demersum and Myriophyllum spicatum, and fragments of riparian shrubs of Tamarix sp., Nerium oleander and Salix sp. were also seen here. These vegetation types have not been classified by lack of records.

\section{Ajia (district Khidonia)}

Many hydrophilous vegetation types are found at the small, artificial freshwater lake (ca. $0,1 \mathrm{~km}^{2}$ ) near the village of Ajia, occurring in stagnant and running water,

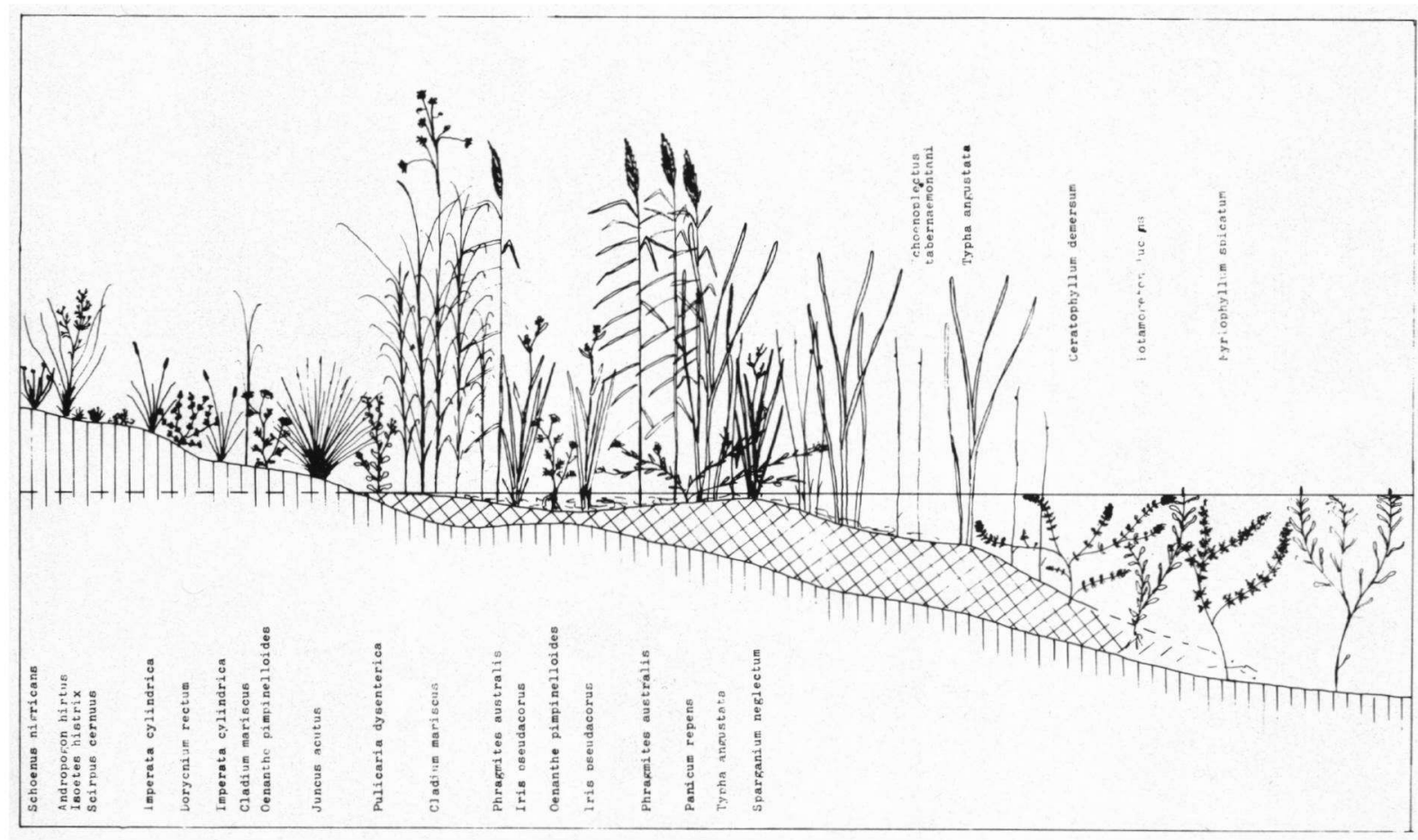

Fig. 3. Zonation of hydrophylous vegetations at the lake near Ajia. 
on steep or gently sloping banks and on moist slopes surrounding the lake. They belong to the Potametum lucentis, Scirpetum maritimi (without Scirpus maritimus!), Dorycnio-Cladietum marisci, Dorycnio-Caricetum otrubae, Apium nodiflorum-Juncus articulatus comm., Carex divisaOenanthe pimpinelloides comm. and the therophytic JuncoIsoetetum hystricis.

The zonation of the hydrophilous shore vegetation is schematically shown in Fig. 3.

4. Topolia (district Kissamos)

In the neogene limestone hills at Topolia $(100 \mathrm{~m})$ springwood vegetation belonging to the Platanus orientalisEquisetum telmateia community is locally seen. The riparian Platanetum orientalis is well-developed here along the river Giflos.

5. Koutsomatadhos (district Kissamos)

Several hydrophilous vegetation types are present along rivulets in the well-irrigated schistose mountains at Koutsomatadhos $(250 \mathrm{~m})$, e.g. Oxyrrhynchietum rusciforme (a monospecific moss-community), Apietum nodiflorum, Caricetum creticae and Castanea sativa community (Fig. 4). At springs the Acrocladio-Adiantetum is found.

6. Fasas valley between Skines and Nea Roumata (district Selinos)

The Fasas valley $(150-300 \mathrm{~m})$, which was explored previously by K. H. Rechinger in 1942 (Rechinger 1944) and W. Greuter in 1962 (Greuter 1973), is probably the most humid valley of Crete. In the upstream part of the valley three vegetation types of the BrachypodioHoloschoenion all. nov. are seen along the river, while steep, dripping wet schistose rocks harbour the AcrocladioAdiantetum and many rare bryophytes (Gradstein 1971).

7. Omalos (district Selinos)

The Omalos (1000-1100 m.) is a vast mountain plain in

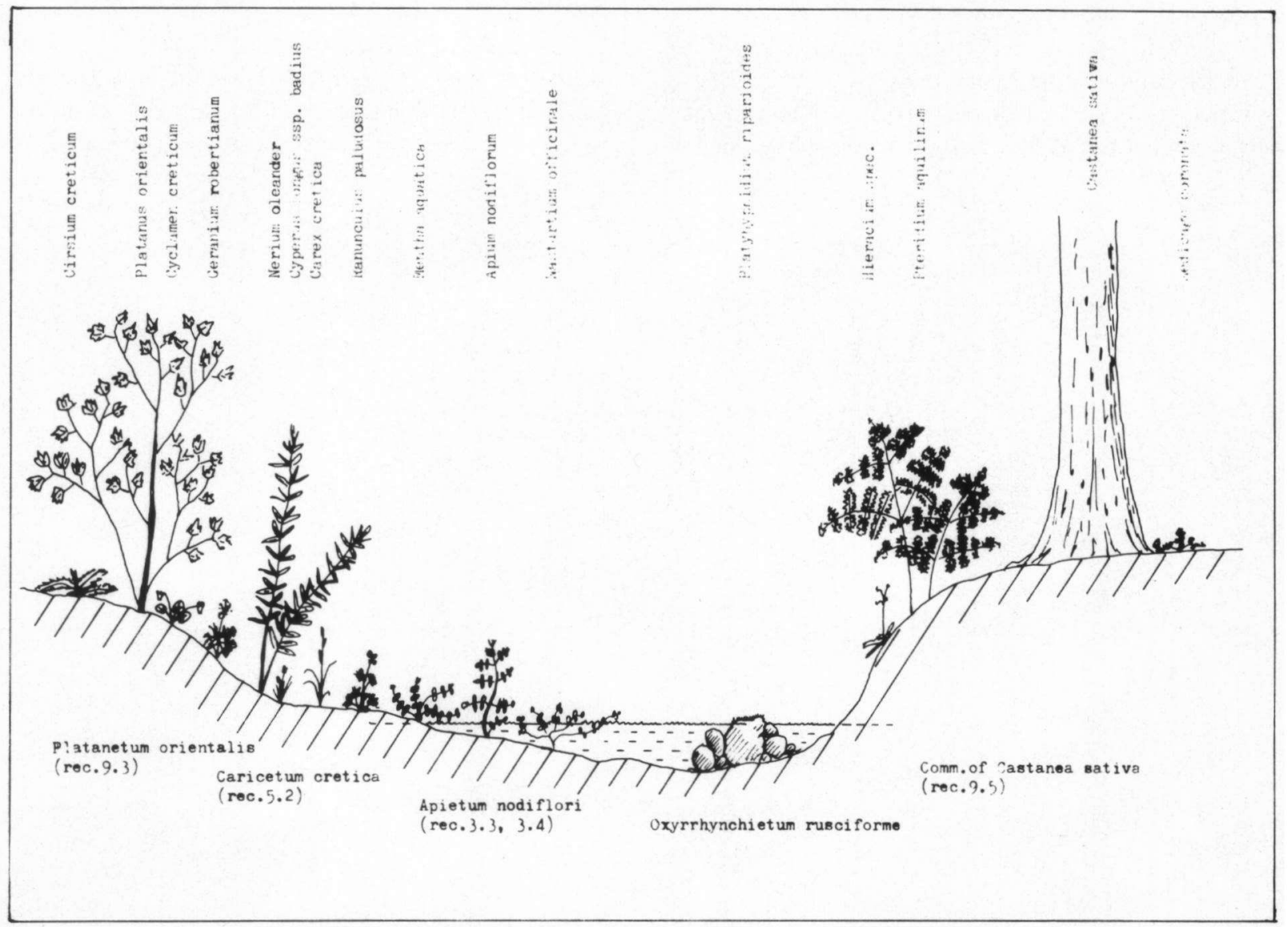

Fig. 4. Zonation of riparian communities at Koutsomatadhos. 
the Levka Ori, where thousands of sheep are grazing part of the year. Hydrophilous vegetation types observed here included the Ranunculetum peltati and the Montia fontana ssp. chondrosperma comm.

\section{Gorge of Samaria (district Sfakia)}

In the $18 \mathrm{~km}$ long gorge of Samaria, which extends from the Omalos to the South coast, a spring vegetation belonging to the Eucladio-Adiantetum was studied.

\section{Description of plant communities}

POTAMETEA R. Tüx. et Preising 1942 (Table 1)

Communities belonging to this class were observed in pools, irrigation ditches, rivers and in the fresh-water lake at Ajia. On the basis of vegetation-records available, four communities are distinguished. The classification follows the treatment of the Potametea in Westhoff \& Den Held (1969).

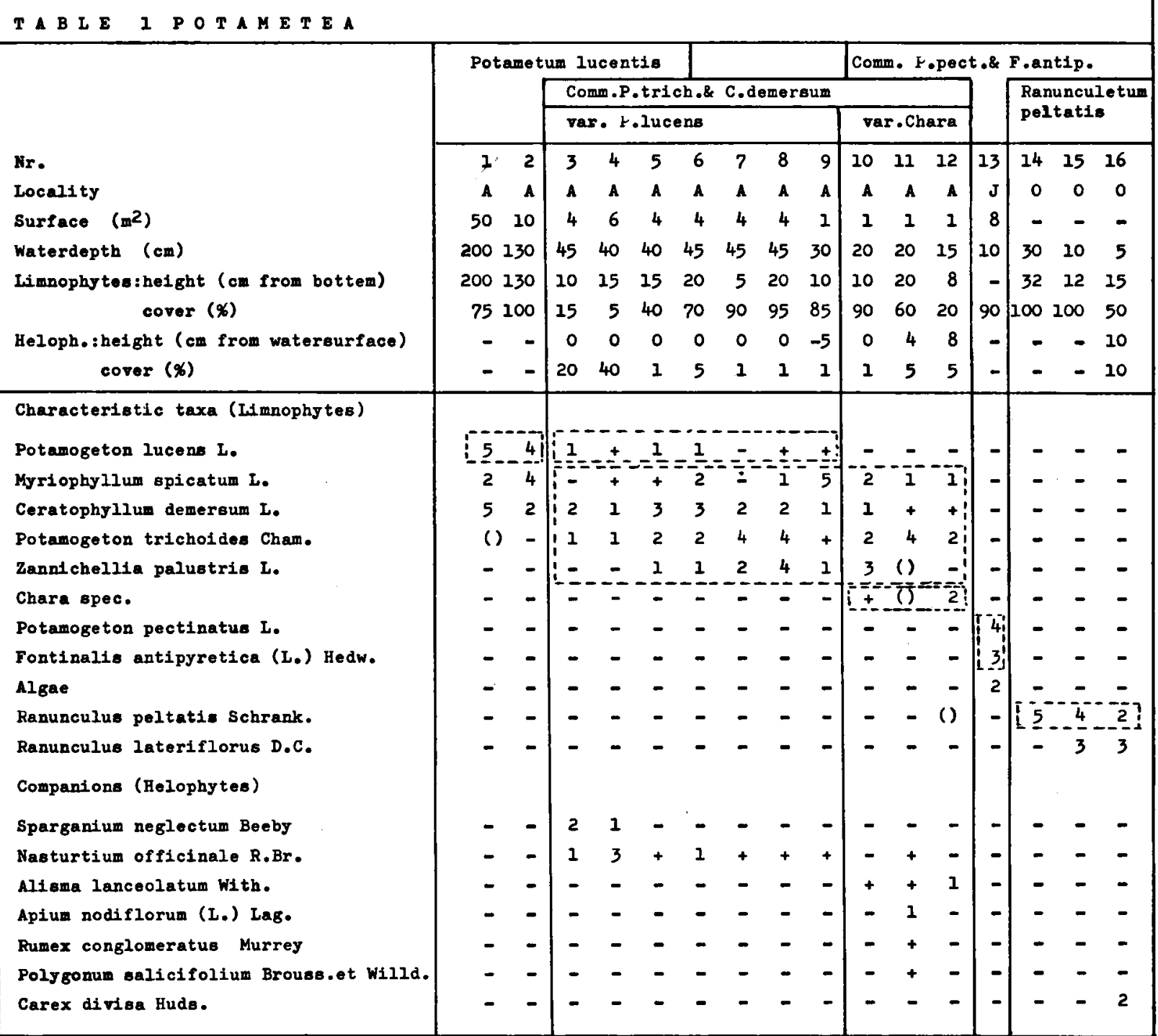


MAGNOPOTAMION Den Hartog et Segal 1964

Potametum lucentis Hueck 1931

c.t.*: Potamogeton lucens.

This association is common in the lake at Ajia at waterdepths of 1-3 meter. The vegetation is composed of three large aquatic species: Potamogeton lucens, Ceratophyllum demersum and Myriophyllum spicatum. The substrate consists of a layer of very weak mud and sapropelium of over $50 \mathrm{~cm}$. in thickness. Above the water-surface the community is recognized from a distance by the inflorescence of Potamogeton lucens. In shallow water close to the shore Potamogeton lucens is rare. Here the association is replaced by the next community.

PARVOPOTAMION Den Hartog et Segal 1964

Community of Potamogeton trichoides and Ceratophyllum demersum

c.t.: Potamogeton trichoides, Ceratophyllum demersum, Zannichellia palustris, Myriophyllum spicatum.

This community occurs along the shore of the lake of Ajia close to the mouth of the river, in shallow, slowly running water of up to $50 \mathrm{~cm}$ deep. The substrate is rather solid and poor in sapropelium. The community is floristically richer than the previous association and great variation in dominance and abundance is observed among the constituing species. The community occurs close to the Apietum nodiflori, as is indicated by the presence of Nasturtium officinale and Sparganium.

Within the community two variants are distinguished: I. variant with Potamogeton lucens in deeper water. Potamogeton lucens is small here, and invariably sterile; 2. variant with Chara, in very shallow water at the shore. With Chara sp., Ranunculus aquaticus and Alisma lanceolatum.

Community of Potamogeton pectinatus and Fontinalis antipyretica (Parvopotamion?)

c.t.: Potamogeton pectinatus, Fontinalis antipyretica.

This community occurs in a brooklet behind the dunes at Jeorjioupolis, in fastly running, brackish water of up to $10 \mathrm{~cm}$ deep, on solid, gravelly soil. The vegetation contains several species of Algae which were not identified. The occurrence of the moss Fontinalis antipyretica in brackish water is unusual (Welch 1957). The lax and relatively flatleaved form of this species found here probably is a habitatmodification.

* Characteristic taxon or characteristic combination of taxa.
Dense masses of Potamogeton pectinatus also occur in much deeper water in the river at Jeorjioupolis.

\section{CALLITRICHO-BATRACHION Den Hartog et Segal 1964 \\ Ranunculetum peltati (Sauer) Segal 1967 \\ c.t.: Ranunculus aquatilis ssp. peltatus.}

Fragments of this association occur in artificial drinkingpools with stagnant water, up to $50 \mathrm{~cm}$ deep. They were seen in the lowlands and in the mountains up to $1000 \mathrm{~m}$ in altitude. $R$. aquatilis ssp. peltatus is usually the only flowering plant in this vegetation. At the bank of pools, in shallow water up to $10 \mathrm{~cm}$ deep, $R$. aquatilis ssp. peltatus grows together with sterile plants of the endemic Ranunculus lateriflorus var. pumilus. The latter taxon flowers only on drier soil on the edge of the pool in stands of Carex divisa. Therefore we cannot consider $R$. lateriflorus a (local) characteristic taxon of the Ranunculetum peltati.

ADIANTETEA Br.-Bl. 1947 (Table 2)

ADIANTETALIA Br.-Bl. 1931

\section{ADIANTION Br.-Bl. 1931}

c.t.: Adiantum capillus-veneris, Samolus valerandi.

This is a strictly Mediterranean alliance, comprising communities of low herbs, ferns and bryophytes occurring on moist and shaded rocks or cliffs, near springs. On Crete such communities are common in the mountains up to $800 \mathrm{~m}$. They are easily recognized by the presence of Adiantum capillus-veneris or Samolus valerandi. It should be noted that Samolus valerandi is not a faithful species of this alliance on Crete since it is also seen along the coast in saline communities belonging to the Phragmitetea or Juncetea maritimi. Possibly two different ecotypes of Samolus valerandi are at hand. On the Canary Islands Samolus valerandi seems to be entirely confined to the Adiantion (Sunding 1972).

\section{Eucladio-Adiantetum Br.-Bl. 1931 \\ c.t.: Eucladium verticillatum, Cratoneuron commutatum, Schoenus nigricans.}

This community occurs on moist and rather shaded limestone rocks. The mosses in this community are often encrusted in chalk tuff. A good example of this community was seen at a spring in the Gorge of Samaria. The EucladioAdiantetum has been reported from the Yugoslavian coast and the western Mediterranean region (Sunding 1972). 
$\mathrm{Nr}$.

Locality $\left(\mathrm{m}^{2}\right)$

Exposition

Inclination $\left({ }^{\circ}\right)$

Herb-layer height (cm)

cover (\%)

Moss-layer cover (\%)

Characteristic taxa

Adiantum capillus-veneris $\mathbf{L}$.

Samolus valerandi $L$.

Eucladium verticillatum (Brid.) B.S.G.

Cratoneuron commutatum (Hedw.) Roth

Schoenus nigricans L.

Acrocladium cuspidatum (Hedw.) Lindb.

Pellia fabbroniana Raddi

Eurhynchium praelongum (Hedw.) B.S.G.

Scirpus cernuus Vahl.

Lathyrus neurolobus Boiss. et Heldr.

Companions

Cyclamen creticum Hildebr.

Hedera helix L.

Carex halleriana Asso:

Brachypodium sylvaticum (Buds.) R. et $S$.

cf. Leantodon tuberosus L.

Carex distans $\mathrm{L}$.

Arisarum vulgare Targ. - Tozz.

Oenanthe pirpinelloides $\mathrm{L}$.

Agrostis semiverticillata (Forsk.) Christ.

Philonotis marchica (Hedw.) Brid.

Pohlia cruda (Hedw.) Lindb.

Juncus articulatus $L$.

Rubus sanctus schreb.

Luzula forsteri (L.) D.C.

Anacalis tenella L.

Eleocharis multicaulis $\mathrm{Sm}$.

Juncus effusus 1 .

Listera ovata (i.) R. Br.

Anthoxanthum odoritum L.

Erica arborea L.

Cistus incanus L. ssp. creticus (L.) Heywood

\begin{tabular}{|c|c|c|c|c|}
\hline \multirow{2}{*}{\multicolumn{2}{|c|}{ Eucladio-Adiantetum }} & \multicolumn{3}{|c|}{ Acrocladio-Adiantetum } \\
\hline & & \multirow{2}{*}{$\begin{array}{l}\text { var. } \\
\text { Eurh. } \\
3\end{array}$} & \multicolumn{2}{|c|}{ var,Scirpugernuus } \\
\hline 1 & 2 & & 4 & 5 \\
\hline $\begin{array}{l}5 \\
4,5\end{array}$ & $\begin{array}{l}5 \\
2\end{array}$ & $\begin{array}{l}\mathrm{K} \\
0,3\end{array}$ & $\begin{array}{l}F \\
2\end{array}$ & $\begin{array}{l}F \\
2\end{array}$ \\
\hline $\mathbf{S}$ & $\mathbf{s}$ & NW & $\mathbf{N}$ & $N$ \\
\hline 20 & 30 & 25 & 90 & 20 \\
\hline 10 & 10 & - & 2 & 75 \\
\hline 80 & 75 & - & 90 & 80 \\
\hline 75 & 20 & - & 90 & 80 \\
\hline
\end{tabular}

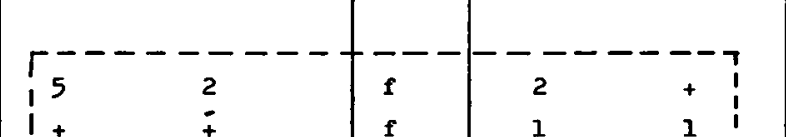

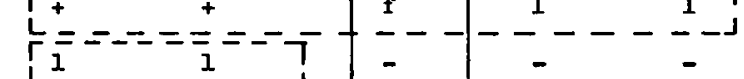

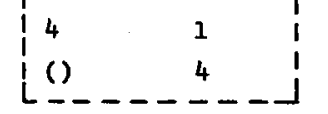

$-$

$-$

$-\quad-$

- $\quad-$

- -

$+1$

$++$

$+\quad+$

1

1

$+$

$+$

$+$

$+$

$$
\text { - }
$$$$
-
$$$$
-
$$$$
\text { - }
$$$$
-\quad-
$$$$
\text { - } \quad-
$$$$
\text { - } \quad-
$$$$
\text { - } \quad-
$$$$
\text { - } \quad-
$$

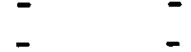$$
\text { - } \quad
$$$$
\text { - }
$$$$
\text { - } \quad-
$$$$
\text { - }
$$

- $\quad-$ 
Acrocladio-Adiantetum ass. nov.

$$
\begin{aligned}
& \text { c.t.: Acrocladium cuspidatum (= Calliergonella cuspi- } \\
& \text { data), Pellia endiviaefolia. }
\end{aligned}
$$

Ecologically the Acrocladio-Adiantetum differs from the previous association by its occurrence on schistose rocks. Typical calciphilous bryophytes, e.g. Eucladium verticillatum and Cratoneuron commutatum, are lacking in this community. Several neutrophilous species are present instead, such as Acrocladium cuspidatum, Eurhynchium praelongum (both very rare on Crete) and Pellia endiviaefolia.

Two variants are distinguished: 1. variant of Eurhynchium praelongum, on rather eutrofic, loamy soil covering schists at an artificial spring near Koutsomatadhos; 2. variant of Scirpus cernuus, on the basis of steep N.exposed schistose rocks along the road in the Fasas valley. This variant is richer in species than the previous variant. Differential species are Scirpus cernuus, Lathyrus neurolobus and several species of bryophytes.

PHRAGMITETEA R. Tüx. et Preising 1942

NASTURTIO-GLYCERETALIA Pignatti 1953

(Syn.: Glycerio-Sparganion Br.-Bl. et Sissing 1942 s.1.)

APION NODIFLORI Segal, in Westhoff \& Den Held 1969 (Table 3)

Apietum nodiflori Br.-Bl. 1931 (sub nom. Heliosciadietum nodiflori)

c.t.: Nasturtium officinale, Apium nodiflorum, Veronica anagallis-aquatica, Mentha aquatica.

The Apietum nodiflori occurs in bands along rivers and rivulets, in shallow running water, in the lowlands and in the lower mountains. It prefers a muddy and almost permanently wet soil. Apium nodiflorum and Nasturtium officinale are always present and either of them may be the dominating species. Apium nodiflorum is probably the most common hydrophilous species of Crete. It is a companion species of several other communities. In the lowlands this is also true for Mentha aquatica, which is a frequent companion species of Holoschoenetalia communities (Table 6). Nasturtium officinale and Veronica anagallis-aquatica probably are faithful species of the Apietum nodiflori on Crete.

At the lake of Ajia in the mouth of the river a variant with Sparganium neglectum occurs on rather solid soil. This variant resembles the Glycerio-Sparganietum Koch from western Europe, but differs in the absence of Glyceria fluitans. This species has not yet been reported from the Aegean region.

Community of Apium nodiflorum and Polygonum salicifolium

c.t.: Polygonum salicifolium, Apium nodiflorum, Typha angustata.

This is a floristically rich community occurring along the shore of the lake at Ajia near the mouth of the river, in 6-15 cm deep, slowly running water. The soil is muddy and permanently wet due to the artificial control of the waterlevel of the lake throughout the year. The community differs from the Apietum nodiflori in the absence of Nasturtium officinale and by the presence of Polygonum salicifolium, Typha angustata and by several Holoschoenetalia taxa, e.g. Rumex conglomeratus, Oenanthe pimpinelloides and Galium constrictum.

Community of Cyperus distachyus and Apium nodiflorum. c.t.: Cyperus distachyus, Apium nodiflorum, Typha angustata, Samolus valerandi, Lemna minor.

This community occurs in brackish swamps near springs just behind the dunes at Jeorjioupolis. Physiognomically the community is characterised by the low and dense mats of Cyperus distachyus alternating with higher tufts of Typha angustata. The community is surrounded by monospecific stands of Juncus heldreichianus and is grazed by mules. The Cretan Cyperus distachyus-Apium nodiflorum community resembles the community of Cyperus distachyus and Polypogon monspeliensis described by Wolff (1968) from the Lagoons of the Mesolonghi in Greece. According to Wolff that community occurs in a brackish habitat periodically flooded by fresh water. The ecology of both vegetation-types needs further study before anything definite can be said about their syntaxonomic position.

\section{PHRAGMITETALIA Koch 1926}

\section{PHRAGMITION Koch 1926 (Table 4)}

On Crete belts of the common reed (Phragmites australis) are rare and restricted to the lowlands, especially the river deltas which do not completely dry up in summer. Floristically the Cretan reed belts differ from the western European reed stands by the presence of the mediterranean species Panicum repens and Typha angustata. The Cretan reed belts are generally rather poor in species. 


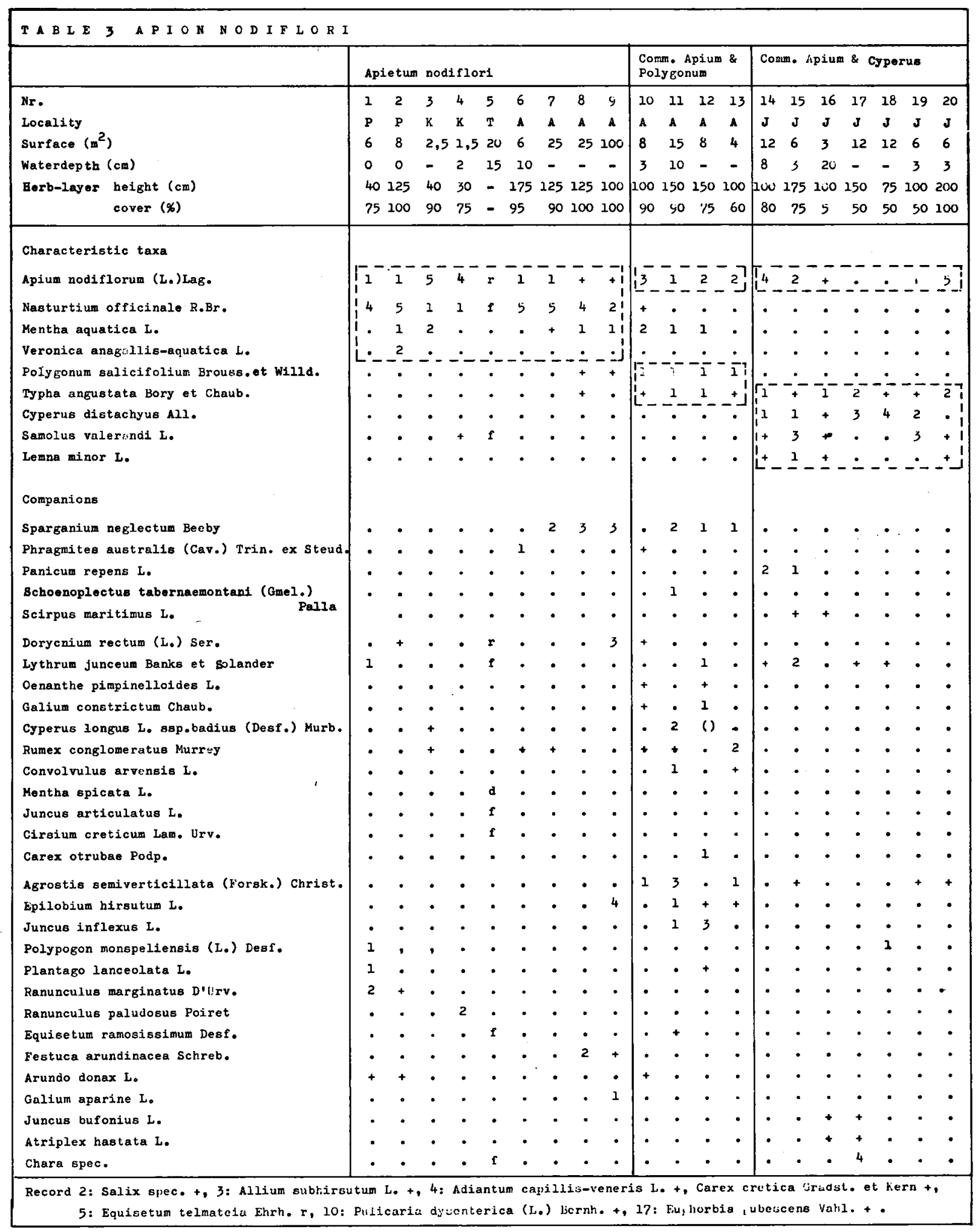




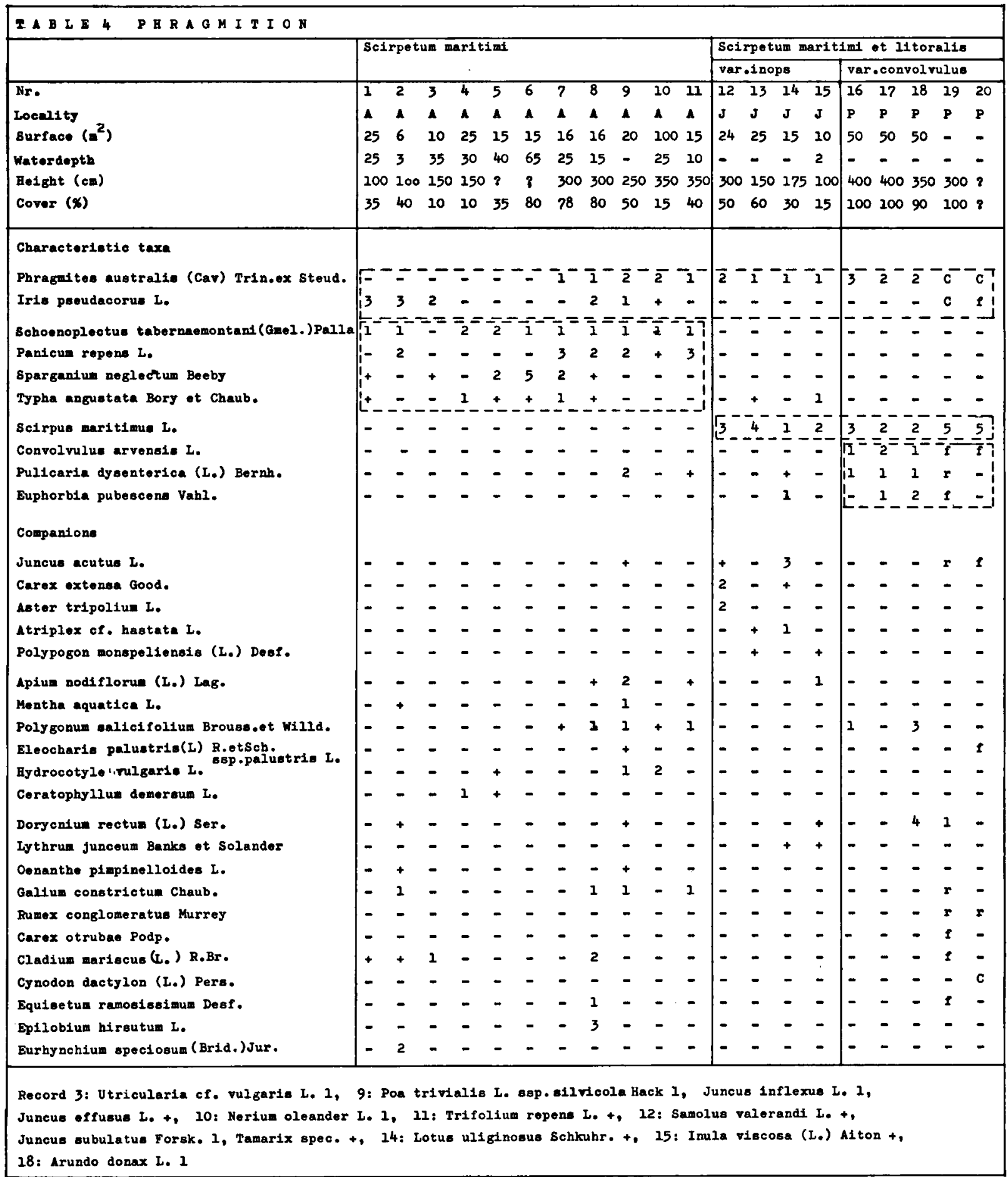


Scirpetum maritimi R. Tüx. 1937

c.t.: Scirpus tabernaemontani, Phragmites australis, Panicum repens, Sparganium neglectum.

The reed belts along the shore of the freshwater lake at Ajia apparently belong to this association because of the presence of the faithful species Schoenoplectus tabernaemontani. We did not see Scirpus maritimus there. The reed vegetation occurs in shallow, stagnant water up to $60 \mathrm{~cm}$ deep. The substrate consists of a weak and almost impassable layer of decaying plant material up to $1 \mathrm{~m}$ in thickness. Phragmites australis thrives best in water of 15-30 cm deep whereas Panicum repens is more common in shallow water close to the shore. Schoenoplectus tabernaemontani is evenly distributed throughout the reed belt. Between the Phragmites belt and the Potametum lucentis of the open water (Fig. 3), a narrow zone of Schoenoplectus tabernaemontani, Typha angustata and Sparganium neglectum is seen. This vegetation develops at water depths of $30-60 \mathrm{~cm}$ on a very weak layer of plant material washed ashore, and can be considered an initial phase of the Scirpetum maritimi. On firmer substrate Mentha aquatica, Epilobium hirsutum and Hydrocotyle vulgaris may get established in this zone. Phragmites is virtually lacking here.

Locally stands with Iris pseudacorus occur, both within the reed belt and within the stands of Cladium mariscus. The facies of Iris is probably due to a disturbance of the soil, viz. the presence of an old trail.

\section{Scirpetum maritimi et litoralis $\mathrm{Br} .-\mathrm{Bl} .1931$}

c.t.: Scirpus maritimus, Phragmites australis.

This association comprises the coastal reed belts of Crete, occurring in brackish riverdeltas in stagnant or slowly running water. It differs from the previous association mainly by the absence of Scirpus tabernaemontani, Panicum repens and Sparganium neglectum. Two variants are distinguished here: 1 . variant inops, which was seen in the brackish marshes near Jeorjioupolis close to the river. Among the companions there are several halophilous species, e.g. Juncus heldreichianus, Carex extensa and Atriplex cf. hastata; 2. variant of Convolvulus arvensis, differing from the previous variant by the presence of Convolvulus arvensis, Pulicaria dysenterica and Euphorbia pubescens. This variant occurs along the mouth of the river Keritis at Platanias and inhabits a less brackish habitat than the variant inops, as is obvious from the smaller number of halophilous companions. In fact, this variant shows a distinct relationship to the DorycnioCaricetum otrubae (Holoschoenetalia).
MOLINIO-JUNCETEA Br.-Bl. 1947

HOLOSCHOENETALIA Br.-Bl. 1947

c.t.: Juncus articulatus, Juncus effusus, Dorycnium rectum, Lythrum junceum, Oenanthe pimpinelloides, Galium constrictum, Cirsium creticum, Rubus sanctus, Cyperus longus ssp. badius, Carex distans. Published accounts on eastern Mediterranean communities belonging to the Holoschoenetalia are virtually nonexisting. Yet a considerable number of hydrophytic communities on Western Crete apparently belongs to this Mediterranean order. According to Braun-Blanquet et al. (1952: 127) the Holoschoenetalia are comprised of "prairies à végétations assez dense et élevées qui ........ exigent une humidité temporaire elevée, mais supportent le dessèchement-estival". Floristically the Cretan communities differ considerably from the western Mediterranean communities of Holoschoenetalia. Of nine faithful species of class and order listed by Braun-Blanquet only four species are present in Cretan Holoschoenetalia: Juncus articulatus, Oenanthe pimpinelloides, Juncus inflexus and Inula viscosa. On Crete the latter two species are restricted in their occurrence to lowland communities. Among the ten characteristic taxa of the Holoschoenetalia listed above four taxa occur frequently in almost all Cretan communities described here: Dorycnium rectum, Lythrum junceum, Oenanthe pimpinelloides, Galium constrictum. Dorycnium rectum (= Bonjeania recta apud $\mathrm{Br}$.-Bl.) and Galium constrictum are also seen in S. France, but there the species are apparently restricted to one or two communities within the order (Braun-Blanquet et al., l.c.).

The Cretan Holoschoenetalia comprise two groups of communities which differ considerably in floristic composition and in distribution. Therefore we have decided to describe these groups as new alliances: the BrachypodioHoloschoenion, occurring in the (lower) mountains, and the Dorycnio-Rumicion conglomeratae, occurring in the lowlands only.

BRACHYPODIO-HOLOSCHOENION all. nov.(Table 5) c.t.: Holoschoenus romanus, Brachypodium sylvaticum, Mentha spicata s.1., Lathyrus neurolobus.

This alliance comprises communities occurring in the hills and lower mountains between 150 and $400 \mathrm{~m}$ at springs or along rivulets. The soils are wet or humid and do not entirely dry up in summer.

The communities of this alliance are negatively characterised by the absence of characteristic species of the 
TABIS B BACBYPODIO-HOLOSCEOENIOA

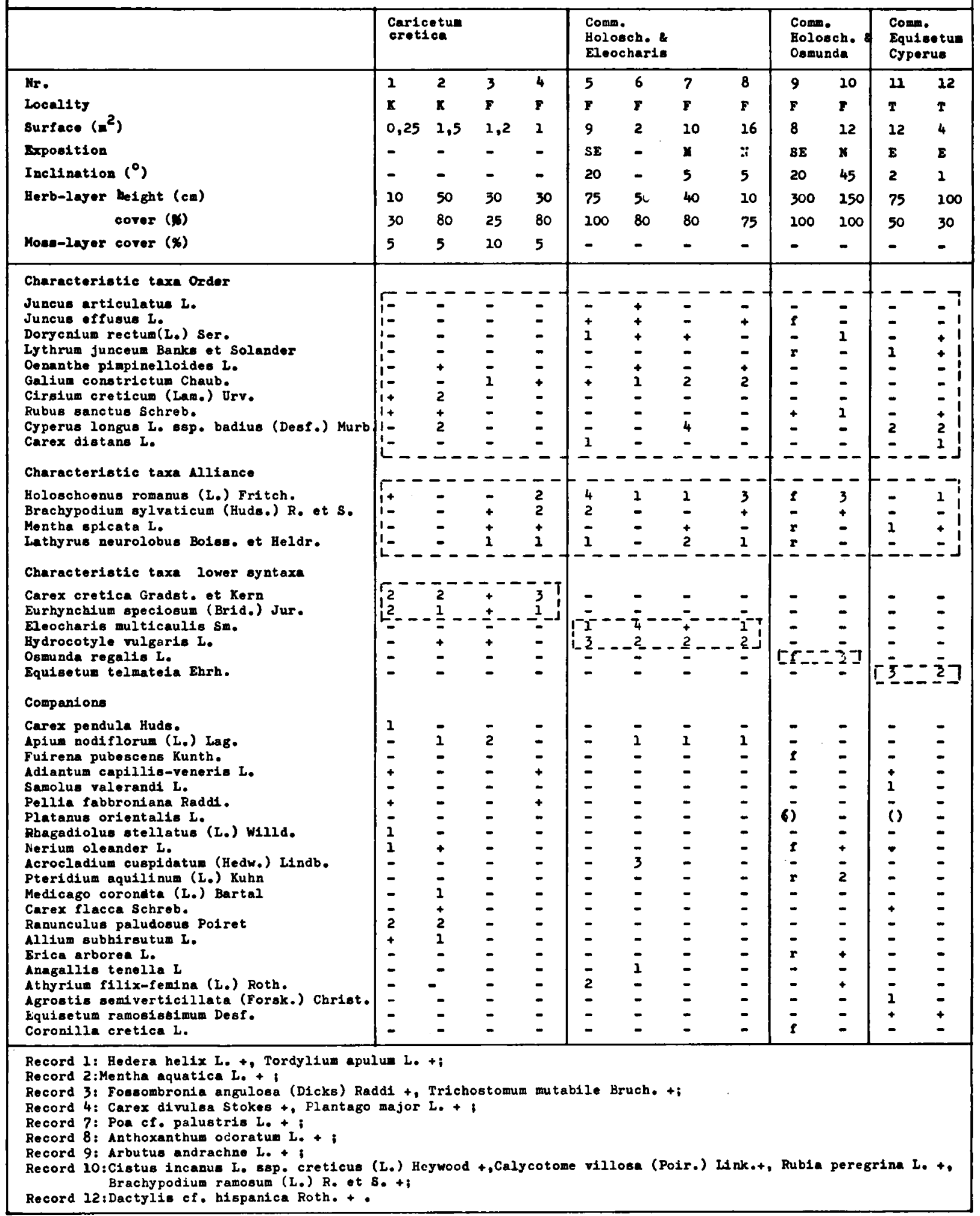


Dorycnio-Rumicion conglomeratae. The only faithful species of the alliance seems to be Brachypodium sylvaticum. The endemic Lathyrus neurolobus is a typical hygrophytic species of the lower mountains in Western Crete; it occurs also in the Acrocladio-Adiantetum (Adiantion).

Caricetum creticae ass. nov.

(Carex cretica-Eurhynchium speciosum consociation, in Gradstein \& Kern 1968)

c.t.: Carex cretica, Eurhynchium speciosum.

This is a riparian community of small herbs and mosses, occurring on rather sunny, flat banks of rivulets in schistmountains at $250-350 \mathrm{~m}$. The Caricetum creticae forms a narrow belt between the Apietum nodiflori and the woodland communities of Platanus orientalis or Castanea sativa, and is accompanied by a number of species from these contiguous communities (Fig. 4). On rather steep banks, where the Apietum nodiflori is lacking, the association is hardly developed as a separate community. Here Carex cretica occurs scattered at the edge of the running water together with Carex remota, in the shade of plane trees.

\section{Community of Holoschoenus romanus and Eleocharis multicaulis}

c.t.: Eleocharis multicaulis, Holoschoenus romanus ssp. australis, Hydrocotyle vulgaris.

This community was observed in the Fasas valley east of Lagous, on a slope along the southern branch of the river near the spring. It represents a rare type of "spring-marsh" vegetation, apparently not yet reported from other Mediterranean regions. The soil is muddy or almost peaty and is flooded by the spring and by the rivulet. The community covers a fairly large area and is rather poor in species. Bryophytes are almost lacking. Eleocharis multicaulis is most abundant close to the spring. Here the community borders the Acrocladio-Adiantetum as is seen by the presence of Acrocladium and Anagallis tenella. Further downstream in running water the community is replaced by almost pure stands of Cyperus longus ssp. badius.

Community of Holoschoenus romanus and Osmunda regalis

c.t.: Osmunda regalis, Holoschoenus romanus ssp. australis, Rubus sanctus.

Like the previous community this vegetation was only seen in the Fasas valley, at springs on steep river banks in the macquis. The soil is permanently wet and permeated by numerous roots of herbs and shrubs. The vegetation is dense and scrubby and contains several elements of the surrounding macquis, viz. Erica arborea and Pteridium aquilinum.

Community of Equisetum telmateia and Cyperus longus c.t.: Cyperus longus ssp. badius, Equisetum telmateia. This vegetation borders the community of Equisetum telmateia and Platanus orientalis (Platanion) at a spring in the valley near Topolia. In contrast with the other communities of the Brachypodio-Holoschoenion this community occurs in a limestone area on periodically desiocating soil. At the time of our visit the soil was almost dry, and the vegetation was slightly disturbed due to grazing by mules. Lythrum junceum, Cirsium creticum and Mentha spicata frequently occur in this community.

DORYCNIO-RUMICION CONGLOMERATAE all. nov. (Table 6)

c.t.: Rumex conglomeratus, Poa trivialis spp. silvicola, Trifolium repens, Orchis laxiflora, Pulicaria dysenterica, Inula viscosa (aff.: Lotus uliginosus, Juncus inflexus, Epilobium hirsutum).

In the lowlands of Western Crete several hydrophytic communities occur in "dynamic" habitats undergoing considerable periodic changes in waterlevel or moisture of the soil. Ecologically and floristically these communities are related to the Agropyro-Rumicion crispi from Western and Central Europe (cf. Westhoff \& Den Held 1969: 107-111). We also see a relationship to the Magnocaricion in which we had tentatively placed some of these communities (Gradstein \& Smittenberg 1968). However, true Magnocaricion communities seem to be lacking on Crete. We have decided to place these lowland communities in a separate alliance of Holoschoenetalia, characterised by a number of wide-spread hygrophytic species. Holoschoenus romanus occurs only rarely in the lowlands and is a characteristic species of the previous alliance.

Dorycnio-Caricetum otrubae ass. nov.

c.t.: Carex otrubae, Dorycnium rectum, Convolvulus arvensis, Lythrum junceum, Juncus effusus, Carex hispida, Cyperus longus ssp. badius.

This association is not uncommon in ditches at roadsides or along lakes and pools, on muddy soil drying up in summer. The association occurs on several places around the lake near Ajia. Well-developed stands were also seen in a freshwater pool at the coast near Jeorjioupolis. Fragments of the association, characterised by the occurrence of i.a. Carex otrubae, Dorycnium rectum and Carex hispida, 


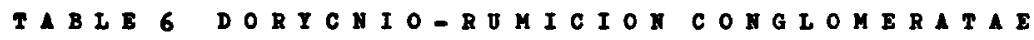

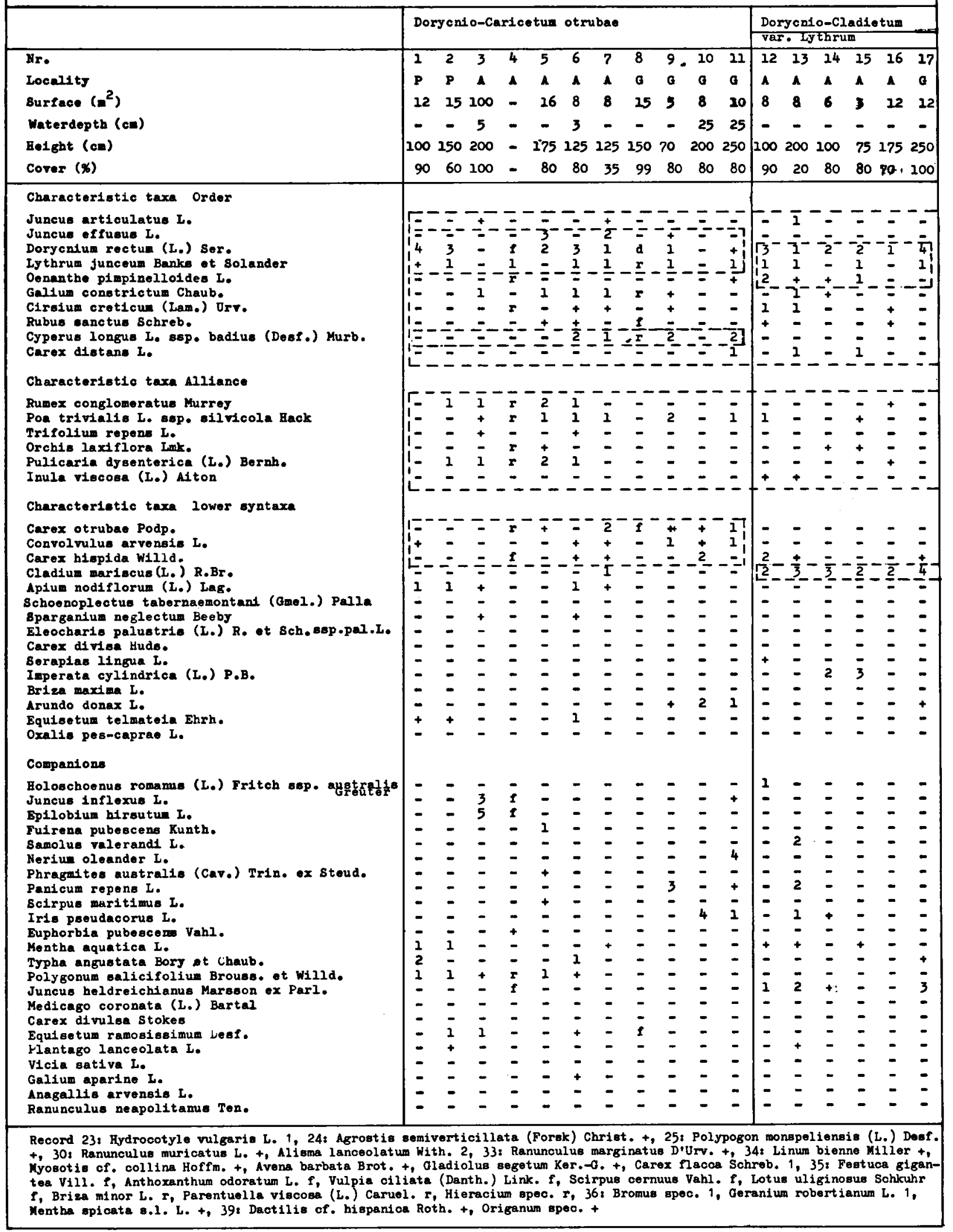




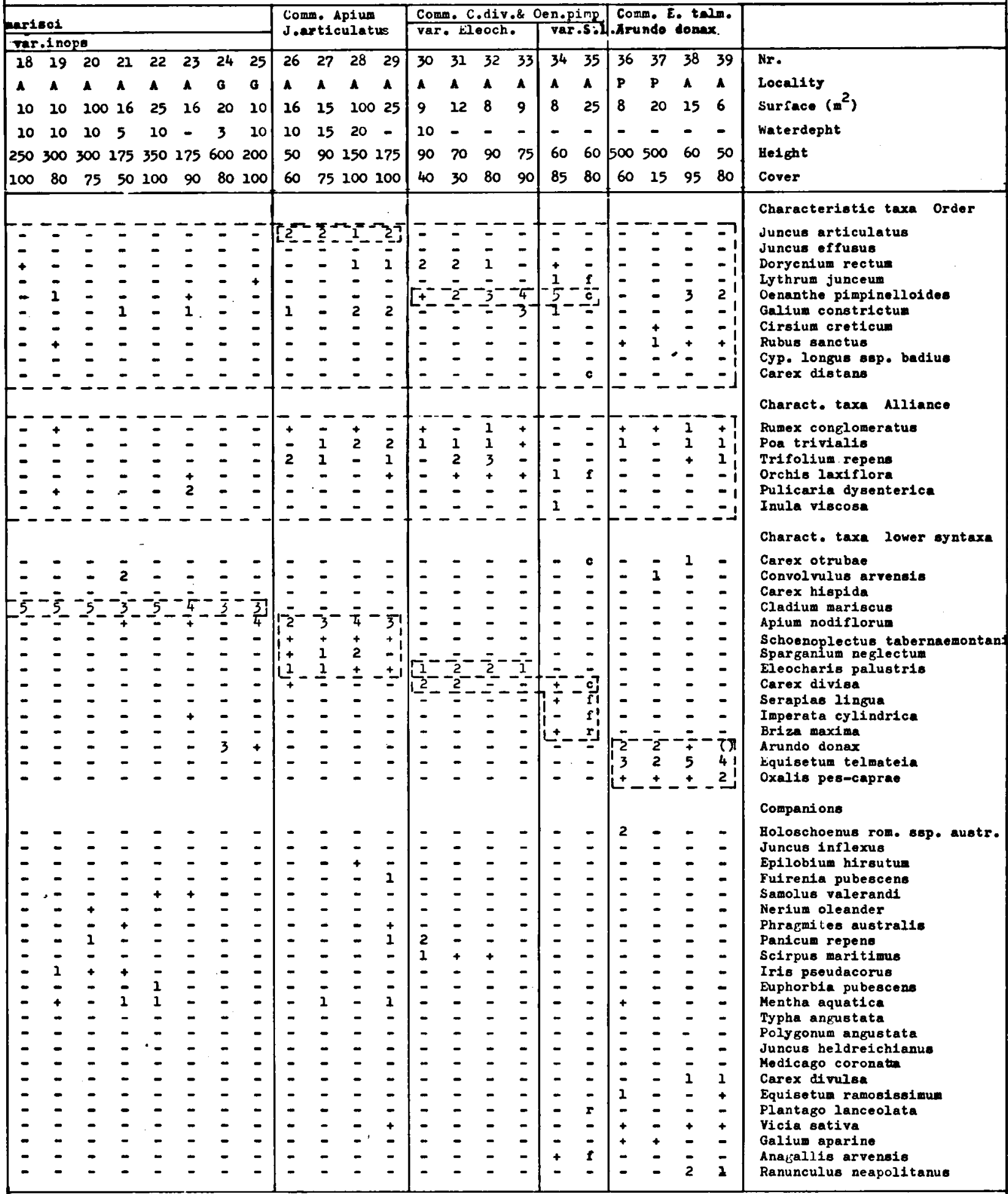

Record 18 Eupatorium glandulosum H., B, ot K, +, 2, Nasturtium officinale R. Br. +, Eloocharis palustris R. ot Sch. Bep. unigl umis (Link) Hartm. + , 5s Lathyrus nourolobus Boiss. et Heldr. + , 6 i Lathyrus nourolobus Boigs. ot Heldr. +, d: Phalaris nodose L. $r$, Oryropsis miliaces (L.) Asch-Schw. $r$, Elytrichia spec. $f$, Lotus uliginoeus Schkuhs $r$, 9 ; Sonchue glaucescens Jordan +, 12: Agrostis semiverticillata (Forsk.) Christ 1, Sonchus glaucescens Jordan 1, Cymodon dactylon (L.) Pers. 1, 138 Anagallis tonella L. 1, Gaudinia fragilis (L.) Pal. 1, 19: Festuca arundinacoa Schreb.1 
are often present in ditches in the coastal areas where the soil may be slightly brackish.

The Dorycnio-Caricetum otrubae is somewhat related to the Cypero-Caricetum otrubae $\mathbf{R}$. Tüx. described from Spain, which was placed in the Magnocaricion (Tüxen \& Oberdorfer 1958). Cyperus longus and Carex otrubae are typical for both associations. Otherwise the two associations differ entirely in floristic composition.

Dorycnio-Cladietum marisci ass. nov.

c.t.: Cladium mariscus.

At Ajia and at Jeorjioupolis vegetations with Cladium mariscus occur, on gradually sloping, wet soil. The soil does not dry up in summer which may partly be caused by percolation of ground water. At Ajia the association forms a rather wide belt between the wet Scirpetum maritimi (Phragmition) and the dryer community of Carex divisa and Oenanthe pimpinelloides (Dorycnio-Rumicion).

Two variants are distinguished: 1. variant of Lythrum junceum, comprising drier phases of the association in which Cladium occurs scattered, together with several species of Holoschoenetalia. Dorycnium rectum, Lythrum junceum and Oenanthe pimpinelloides are particularly common here. This variant is found on rather solid soil in up to $20 \mathrm{~cm}$ deep, stagnant water. 2. variant inops, a facies of Cladium mariscus occurring next to the previous variant in deeper water (up to $40 \mathrm{~cm}$ ). This variant is hardly different from monospecific Cladium mariscus communities, well-known from atlantic and continental Europe, which are generally put in the Magnocaricion Koch (cf. Westhoff \& Den Held 1969).

The Cretan "Cladietum marisci", described here as a new association Dorycnio-Cladietum marisci, may best be compared with the western-mediterranean GentianetoMariscetum Mol. \& Talon 1950 (Holoschoenetalia), which is characterised by e.g. Gentiana pneumonanthe and Mariscus serratus (= Cladium mariscus). The reason for putting the Gentianeto-Mariscetum in the Holoschoenetalia in stead of the Magnocaricion was given by BraunBlanquet et al. (1952: 134) as follows: "Au point de vue évolutif, elle [Gentianeto-Mariscetum] forme la transition entre les Phragmitetalia et les Holoschoenetalia .......... Avec l'augmentation de l'humidité, Mariscus serratus devient de plus en plus envahissant et exclut toutes les espèces caractéristiques. Le groupement se rapproche alors du Mariscetum serrati $\mathrm{W}$. Koch, mais sans pouvoir y être assimilé. La mème remarque s'applique au groupements à Mariscus signalé par Horvatic de la Dalmatie et par Rivas Goday et Asensio Amor de l'Espagne". In our opinion this remark is also true for the Cretan DorycnioCladietum marisci.

Community of Apium nodiflorum and Juncus articulatus c.t.: Juncus articulatus, Apium nodiflorum, Eleocharis palustris, Schoenoplectus tabernaemontani, Sparganium neglectum.

This community occurs at the eastern side of the lake near Ajia in an area of flooded arable fields, on muddy soil in 10-20 cm deep water. Juncus articulatus and Eleocharis palustris are the most characteristic species in this habitat. The abundance of Apium and the presence of Schoenoplectus tabernaemontani and Sparganium neglectum indicate a close relationship to the Phragmitetea.

Community of Carex divisa and Oenanthe pimpinelloides c.t.: Carex divisa, Oenanthe pimpinelloides, Orchis laxiflora.

This community occurs near Ajia on the edges of a pool and along the northern bank of the lake. It is a humid prairie of rather low sedges, rushes, and grasses, in which several species of orchids occur, e.g. Serapias lingua and Orchis laxiflora. The vegetation thrives on humid, loamy soil which superficially dries up in summer. The community forms a colourful belt between the wet Phragmition and the drier prairies on the slopes surrounding the lake.

Two variants are distinguished: 1. variant of Eleocharis palustris, on relatively wet soil. Differential species are Eleocharis palustris, Dorycnium rectum, Poa trivialis, and Trifolium repens. Carex divisa has its optimal occurrence in this variant. 2. variant of Serapias lingua; drier than the previous variant from which it differs by the presence of Serapias lingua, Imperata cylindrica, Briza maxima, and several elements of the prairies. Oenanthe pimpinelloides is most abundant in this variant.

\section{Community of Equisetum telmateia and Arundo donax}

c.t.: Equisetum telmateia, Arundo donax, Oxalis pescaprae, Rubus sanctus, Rumex conglomeratus.

Equisetum telmateia is a characteristic species of shaded, sloping habitats with almost permanent humidity due to percolation of groundwater. Near Topolia at ca. $200 \mathrm{~m}$ the species was seen once in a springgrove community with Platanus orientalis. Near the coast at Platanias and Ajia the species grows next to stands of the bamboo-reed (Arundo donax) on steep gravelly river-banks or (at Ajia) along the lake at the base of the dam. The community of Equisetum telmateia and Arundo is placed in the Dorycnio-Rumicion because of the frequent occurrence of 


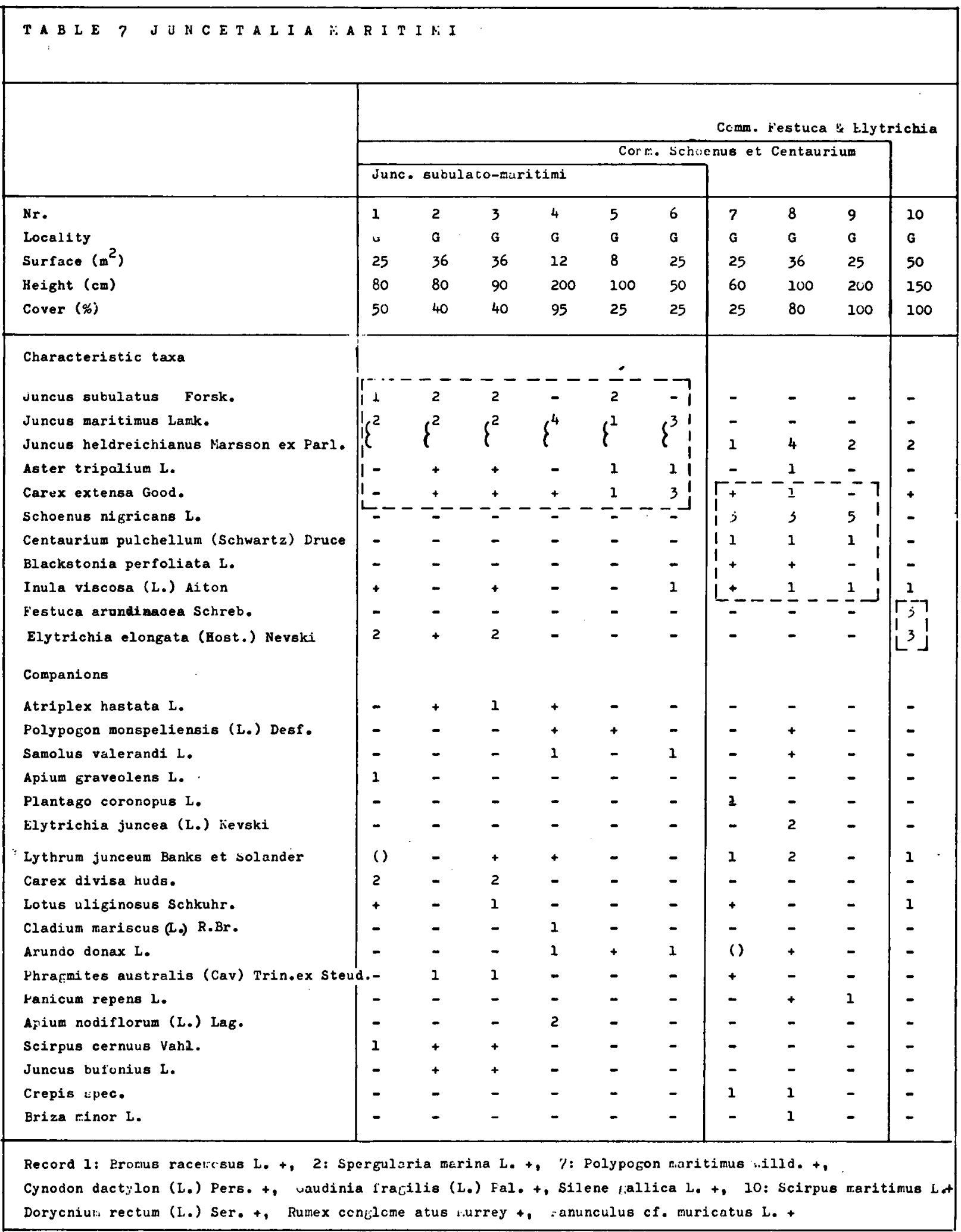


Holoschoenetalia elements, e.g. Rubus sanctus, Rumex conglomeratus, Poa trivialis, and Oenanthe pimpinelloides. Pure stands of Arundo, which are commonly seen along dikes and ditches in arable fields, do not belong here. Their syntaxonomic position is uncertain.

\section{JUNCETEA MARITIMI Br.-Bl. 1931 (Table 7)}

JUNCETALIA MARITIMI Br.-BI. 1931

Alliance?

\section{Juncetum subulato-maritimi ass. nov.} c.t.: Juncus subulatus, Juncus maritimus, Juncus heldreichianus, Carex extensa, Aster tripolium.

This association occurs on brackish alluvial soils along the Cretan coast. The toplayer of the soil desiccates in summer, showing a pattern of cracks. Physiognomically this community is characterised by dense and floristically rather poor mats of Juncus maritimus and J. subulatus, mixed with larger tufts of $J$. heldreichianus. The vegetation is often grazed by mules.

At Jeorjioupolis and at Vai in eastern Crete we saw vast stands of this association in brackish swamps near the beach. Rechinger (1951) reports stands belonging to this association from Iráklio and Ajios Nikoláos.

Communities of Juncus heldreichianus ("acutus") and $J$. maritimus have been recorded from many different areas in the Mediterranean region: France, Venice, Palestine, Egypt and the Canary Islands (Wolff 1968, Sunding 1972). No attempt has been made sofar to clarify the syntaxonomic position of these communities. The confusion existing in the application of the specific epitheta "acutus", "maritimus", and "heldreichianus" to the Juncus species in this vegetation (Greuter 1973: 70) makes this task even more difficult. Some communities have been assigned to the rather heterogenic Juncetum maritimi Pignatti 1953. The Cretan community is well distinguished from the Juncetum maritimi by the presence of Juncus subulatus and therefore is described here as a new association. The Juncetum subulato-maritimi is floristically related to the Scirpetum maritimi et litoralis, and to the coastal scrub of Tamarix spp. (not studied).

Community of Schoenus nigricans and Centaurium pulchellum

c.t.: Schoenus nigricans, Centaurium pulchellum, Blackstonia perfoliata, Inula viscosa, Carex extensa.

This is a typical gradient community which forms a narrow belt at the foot of the dunes near Jeorjioupolis, adjacent to the Juncetum subulato-maritimi. The community is richer in species than the Juncetum subulatomaritimi. Schoenus nigricans is the dominating species. The community has affinity to the west-mediterranean Plantaginion crassifoliae Br.-Bl. 1931. Records of similar communities at the west coast of the Peloponnesos are given by Lavrentiades (1964: 276).

Community of Festuca arundinacea and Elytrigia elongata c.t.: Festuca arundinacea, Elytrigia elongata.

Like the previous community this vegetation was only seen at the coast near Jeorjioupolis. The community of Festuca and Elymus constitutes a meadow of robust grasses between the Juncetum subulato-maritimi and the surrounding arable fields. The soil was rather uneven and dried up at the time of our visit. The presence of Lythrum junceum, Dorycnium rectum and Rumex conglomeratus indicates a relationship to the Dorycnio-Caricetum otrubae (Holoschoenetalia).

ISOETO-NANOJUNCETEA Br.-Bl. \& R. Tüx. 1943

ISOETALIA Br.-Bl. 1931

\section{ISOETION Br.-Bl. 1931 (Table 8)}

This alliance comprises micro-communities of several species of Isoetes and of minute therophytes which are not uncommon in the Mediterranean region and are often overlooked. The communities develop in winter and early spring on hillsides and on tracks in small depressions. The soil in these depressions is humid from late autumn to early spring, favoring germination of the characteristic therophytic species. Seven associations were provisionally assigned to this alliance by Braun-Blanquet (1936). Three of them were only known from N. Africa. Pietsch (1973) lists fourteen associations from the European Mediterranean region. Runemark (1971, p. 6-7) reported communities belonging to this alliance from the Central Aegean area.

\section{Junco-Isoetetum hystricis Allorge 1922}

c.t.: Juncus capitatus, Isoetes hystrix, Juncus bufonius, Euphorbia exigua, Radiola linoides, Briza minor.

This community was seen on hillsides in the Fasas valley on humid loamy soil in a Cistus phrygana, and in a humid meadow of Andropogon hirtus and Imperata cylindrica along the lake of Ajia. The association was originally described from $\mathbf{N}$. Africa. The Cretan community differs from the $\mathbf{N}$. African community by the absence of Laurentia 
T A B L E 8 I S O E T I O N

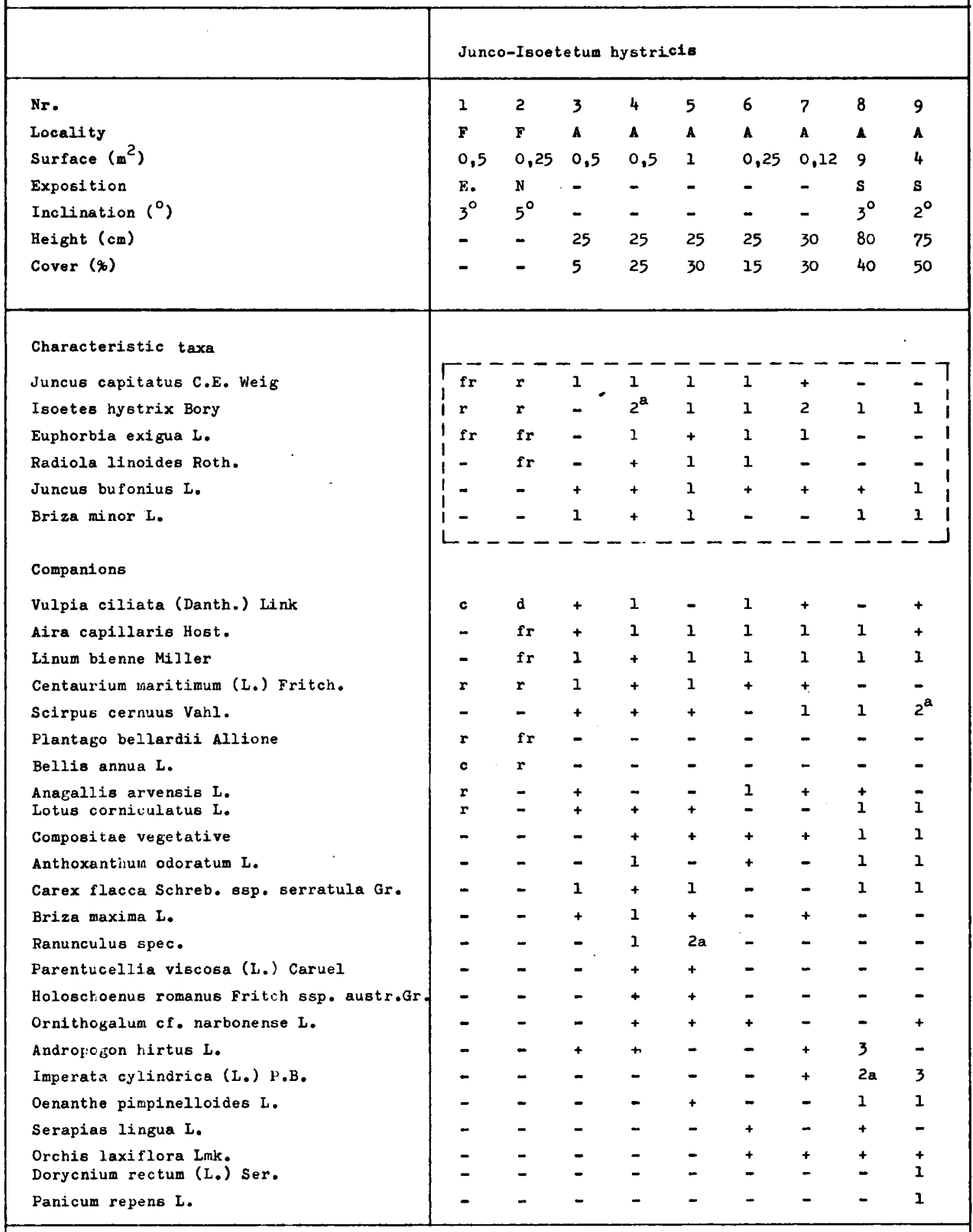

Record 1: Serapias laxiflora Schaub $r$; 2 : Silene colorata Poir. $r$, Tordylium apulum L. $r$; 3: Sagina apetala Ard.+, Gnafalium cf. Uliginosum L. + ; 8: Medicago coronata (L.) Eartal + ; 9: Juncus acutus $L_{.}+$, Mentha aquatica $L_{.}+\cdots$ 
michelii, Cicendia filiformis, and Trifolium micranthum. The latter three species have been reported from the Central Aegean islands by Runemark (l.c.).

\section{NANOCYPERETALIA Klika 1935}

\section{NANOCYPERION FLAVESCENTIS Koch 1926}

\section{Community of Montia fontana ssp. chondrosperma} c.t.: Montia fontana ssp. chondrosperma.

This community was seen once on the Omalos, at ca. $1000 \mathrm{~m}$ in running water close to a spring, on rather muddy gravel. The soil is strongly calcareous and probably dries up entirely in summer. The vegetation is floristically heterogeneous and rather ruderal owing to disturbance by sheep, and is made up of scattered growing plants. We recorded Poa annua (2b), Montia (2a), Holoschoenus romanus ssn. australis (2a) and Stellaria media ssp. postii (2a) as the more frequent taxa. Companions are Ranunculus ficaria (1), $R$. paludosus (1), Sagina apetala (+), Plantago coronopus (+) and Bellis annua (+). Poa annua and Stellaria media are particularly indicative of the ruderal character of the vegetation.

The community is apparently very rare in the eastern Mediterranean region since this is the only known locality of Montia in the Aegean area. In West and Central Europe Montia fontana ssp. chondrosperma (Fenzl) Walters (= Montia fontana ssp. fontana var. chondrosperma Fenzl = Montia verna Néck.) is considered a characteristic taxon of the alliance Nanocyperion flavescentis (e.g. Westhoff \& Den Held 1969), which is the reason why we have, though tentatively, thus classified the Cretan community.

\section{ALNO-POPULETEA Fukarek 1968 (Table 9)}

\section{PLATANION ORIENTALIS I. Karpati 1962}

Platanetum orientalis Auct. (cf. Rechinger 1951, Zohary 1962)

c.t.: Platanus orientalis, Cyclamen creticum (endemic!), Carex distachya, Geranium robertianum, Rhagadiolus stellatus. Parietaria lusitanica, Luzula forsteri, Ranunculus ficaria.

This is the typical riparian woodland which is found in the colline and lower montane zones of the island, both in limestone and in schist areas. Usually the plane-tree groves cover a narrow belt of only 10 to $20 \mathrm{~m}$ wide, on either side of brooks and rivers in rather narrow valleys.
In wider valleys the riparian woodland has virtually disappeared due to cultivation of the fertile banks of the rivers. The herb-layer of the Platanetum varies considerably in floristic composition due to variation in edaphic conditions and human influence. Record 4 was taken in a rather natural stand, characterised by the occurrence of Carex remota and Galium scabrum. On Crete these two species are rare and probably restricted to the Platanetum of the schist mountains in the westernmost part of the island. The other records were made in stands close to arable fields, as is seen by the presence of ruderal and segetal companions, e.g. Arum italicum, Euphorbia peplus, Medicago coronata and Ranunculus chaerophyllus.

The Platanetum orientalis seems to be wide-spread and common in the Aegean region (Rechinger 1951).

\section{Community of Castanea sativa}

c.t.: Castanea sativa, Pteridium aquilinum.

In the westernmost part of the island (highlands of Elos) the riparian Platanetum orientalis is sometimes replaced by groves of Castanea sativa. According to Rechinger (1951) Castanea sativa is restricted on Crete to this area and is found only on rather acid soils (schists?) along rivulets. The community comprises several characteristic elements of the Platanetum, e.g. Cyclamen creticum, Rhagadiolus stellatus, and Parietaria lusitanica.

The herb-layer is locally dominated by Pteridium aquilinum, which is a typical species of mediterranean Castanea woods.

Community of Platanus orientalis and Equisetum telmateia c.t.: Platanus orientalis, Equisetum telmateia.

This is a typical spring-grove community which was seen only once on a wet and slippery slope at a spring near Topolia, under large trees of Platanus orientalis. Equisetum telmateia occurs here in a dense stand over an area of at least $300 \mathrm{~m}^{2}$. The wet soil is covered by leaves of the plane trees. Only few companion species are seen in this community, most of them taxa of the Adiantion (Adiantum speculum-veneris, Samolus valerandi) or Holoschoenetalia (Dorycnium rectum, Rubus sanctus, Cirsium creticum). Hedera helix grows abundantly up the stems of the plane trees and locally also covers the soil.

\section{Summary}

The hydrophilous plant communities of Western Crete described and classified in this paper belong to the follow- 
T A B L E 9 P L A T A N I O N O R I E N T A L I S

Comm. Platanus \& Equisetum

Comm. Castanea sativa

Platanetum orientalis

$\mathrm{Nr}$.

Locality ${ }^{2}$ )

Tree-layer height (m)

cover (\%)

Shrub-layer height (m)

cover ( $\%)$

Herb-layer height (cm)

cover (\%)

Moss-layer cover (\%)

\begin{tabular}{llll|l|l}
$\mathrm{I}$ & 2 & 3 & $\mathbf{4}$ & $\mathbf{5}$ & 6 \\
$\mathrm{~T}$ & $\mathrm{~K}$ & $\mathrm{~K}$ & $\mathbf{F}$ & $\mathrm{K}$ & $\mathrm{T}$ \\
70 & 50 & 5 & 20 & 50 & 100 \\
15 & 12 & - & 9 & 15 & 10 \\
15 & 10 & - & 30 & 5 & 15 \\
- & - & 4 & 3 & - & - \\
- & - & 10 & 5 & - & - \\
75 & 45 & 75 & 100 & 75 & 75 \\
15 & 40 & 80 & 25 & 60 & 30 \\
5 & 1 & - & - & - & 1
\end{tabular}

Characteristic taxa

Platanus orientalis L.

Cyclamen creticum Hildebr.

Carex distachya Desf.

Geranium robertianum L.

Rhagadiolus stellatus ( L.) Willd.

Parietaria lusetanica $\mathrm{I}$.

Luzula forsteri (L.) DC.

Ranunculus ficaria $\mathrm{L}$.

Castanea sativa viller

Fteridium aquilinum (L.) Kuhn

Equisetum telmateia Lhrh.

Companions

Nerium oleander $\mathrm{L}$.

Galium aparine $L$,

Euphorbla characias I.

Melica rectiflora Boiss. et Heldr. -

Dryopteris pallida (Bory) Fomin.

Cardamine graeca L.

Brachypodium sylvaticum (Huds.) R. et $S$.

Rubia peretrina $L$.

Athyrium filix-femina ( $L_{0}$ ) Roth.

Carex cretica Gradst. et Kern

Holoschoenus romanus (I.) Fritch.

Carex flacca Schreb.

Hedera helix L.

Eucladium verticillatum (Brid.) B.S.G.

Samolus valerandi $L$.

Adiantum capillis-veneris $I$.

Oenanthe pimpinelloides L.

Tordylium apulum L.

Arisarum vulgare Targ•-Tozz

Cardamine hirsuta $I$.

Selaginella dentata $L$.

Carex divulsa Stokes

Melica minuta L.

Kanunculus paludosus Poiret

Arum italicum Mill.

Euphorbia peplus L.

Bromus sterilis $L$.

cf. Orlaya grandiflora (L.) Hoffm.

Medicago coronata (L.) Bartal.

Veronica cymbalaria Bodard.

Muscari comosum (L.) liiller

Sherardia arvensis $\mathrm{L}$.

Hieracium spec.

Fissidens bryoides Hedw.

Lunularia cruciata (L) Dum.

\begin{tabular}{|c|c|c|c|c|c|}
\hline $5-$ & -- & - & -7 & & \\
\hline 12 & 2 & 1 & 2 & - & 2 \\
\hline 1 & 1 & 1 & 1 & + & - \\
\hline i & $=$ & + & +1 & - & - \\
\hline $1+$ & 1 & 1 & +1 & + & - \\
\hline+ & 2 & 1 & -1 & 1 & - \\
\hline $1+$ & + & 1 & -1 & 1 & - \\
\hline $1-$ & t & + & +1 & + & - \\
\hline L_ & 2 & \pm & $=1$ & $=$ & - \\
\hline$\cdots$ & - & & - & 1 & - \\
\hline- & - & - & - & 2 & $1=$ \\
\hline - & - & - & - & - & ᄂ 3 \\
\hline+ & () & 2 & 2 & - & 2 \\
\hline 1 & + & 1 & + & + & - \\
\hline 2 & - & - & - & - & + \\
\hline 1 & - & - & - & - & - \\
\hline 1 & - & - & - & - & - \\
\hline 1 & - & - & - & - & - \\
\hline - & - & - & 2 & - & - \\
\hline- & - & - & 1 & - & - \\
\hline - & - & - & 1 & - & - \\
\hline - & - & 1 & + & - & - \\
\hline - & - & 1 & + & - & - \\
\hline - & - & - & - & - & 1 \\
\hline - & - & - & - & - & 1 \\
\hline - & - & - & - & - & 1 \\
\hline - & - & - & + & - & + \\
\hline- & - & + & + & - & 1 \\
\hline - & + & 1 & - & - & + \\
\hline - & 1 & 1 & + & - & - \\
\hline - & - & + & + & 1 & - \\
\hline+ & - & + & - & - & - \\
\hline+ & + & - & - & - & + \\
\hline+ & + & - & - & - & - \\
\hline+ & 1 & - & - & - & - \\
\hline - & + & 2 & - & - & - \\
\hline - & + & + & - & - & - \\
\hline - & 1 & 1 & - & $I$ & - \\
\hline- & + & 1 & - & + & - \\
\hline - & + & 1 & - & + & - \\
\hline+ & + & + & - & 2 & - \\
\hline+ & + & - & - & + & - \\
\hline - & 1 & - & - & + & - \\
\hline - & 1 & - & - & + & - \\
\hline - & - & - & - & 2 & - \\
\hline+ & + & - & - & - & + \\
\hline+ & - & - & - & - & + \\
\hline
\end{tabular}

Rec. 1: Rhynchostegiella tenella (Dicks.) Limpr. +. Fossombronia angulosa (Dicks.) Raddi +

Hec. 2: Reboulia hemisphaerica (L.) Raddi +, Trichostomum mutabile Bruch. +, Bryum cf. donianum Grev. +

Rec. 4: Carex remota L. + , Galium scabrum L. + , Osmunda regalis L. +

Kec. 6: Dorycnium rectum (L.) Ser. + , Cirsium creticum (Lam.) Urv. +, Aloina ambigua B.S.G. Limpr. +

Southbia stillicidorum (Kaddi) Lindb. + , Anthoceros laevis L. $f$, cf. Leiocola turbinata

(Raddi) Buch. + 
ing classes: Potametea, Adiantetea, Phragmitetea, MolinioJuncetea, Juncetea maritimi, Isoeto-Nanojuncetea and Alno-Populetea. Two new alliances and five new associations are described: Brachypodio-Holoschoenion, DorycnioRumicion conglomeratae, Dorycnio-Caricetum otrubae, Dorycnio-Cladietum marisci and Caricetum creticae (all Molinio-Juncetea), Acrocladio-Adiantetum (Adiantetea), and Juncetum subulato-maritimi (Juncetea maritimi).

\section{References}

Braun-Blanquet, J. 1936. Un joyau floristique et phytosociologique, "l'Isoetion mediterranéen". S.I.G.M.A. Comm. 42, 23 pp.

Braun-Blanquet, J., N. Roussine \& R. Nègre. 1952. Les groupements végétaux de la France Méditerranéenne. C.N.R.S. Montpellier. $297 \mathrm{pp}$.

Braun-Blanquet, J. 1964. Pflanzensoziologie. 3 Aufl. Springer Verl. Wien, $865 \mathrm{pp}$.

Gams, H. 1957. Kleine Kryptogamenflora, Bnd. IV. 4. Aufl. Fischer Verl. Stuttgart, 240 pp.

Gradstein, S. R. \& J. H. Smittenberg. 1968. Bron-, beek-, en moerasvegetaties van West Kreta. Doctoraal rapp. Utrecht (polycop.) $87 \mathrm{pp}$.

Gradstein, S. R. \& J. H. Smittenberg. 1968. Hygrophiele vegetaties op Kreta. Contactblad voor Oecologen 4 : 11-12.

Gradstein, S. R. 1971. New or otherwise interesting Bryophytes from Crete. Revue bryol. Lichen. 37: 633-679.

Greuter, W. 1972. The relict element of the flora of Crete and its evolutionary significance. In: D. H. Valentine (ed.), Taxonomy, phytogeography and evolution, pp. 161-177. Academic Piess. London.

Greuter, W. 1973. Additions to the Flora of Crete, 1938-1972. Ann. Mus. Goulandris 1: 15-83.

Lavrentiades, G. J. 1964. The ammophilous vegetation of the Western Peloponnesos Coasts. Vegetatio 12: 221-286.

Oberdorfer, E. 1952. Beitrag zur Kenntnis der nordägäischen Küstenvegetation. Vegetatio 3: 329-349.

Pietsch, W. 1973. Beitrag zur Gliederung der europäischen Zwergbinsengesellschaften (Isoëto-Nanojuncetea Br.-Bl. \& Tüx. 1943). Vegetatio 23: 401-438.

Rechinger, K. H. 1944. Neue Beiträge zur Flora von Kreta. Denkschr. Akad. Wiss. Wien 105 (2,1): 184 pp.

Rechinger, K. H. 1951. Phytogeographia Aegaea. Denkschr. Akad. Wiss. Wien 105 (2,2): 208 pp.

Rechinger, K. H. et al. 1943. Flora Aegaea. Denkschr. Wiss. Wien 105: $924 \mathrm{pp}$.

Runemark, H. 1971. Distribution patterns in the Aegean. In: P. H. Davis, P. C. Harper \& I. C. Hedge (eds.), Plant Life of S.W. Asia, pp. 3-14. Univ. Press Aberdeen. Edinburgh.
Sunding, P. 1972. The vegetation of Gran Canaria. Norsk. Vidensk.-Akad. Oslo Math.-Naturv. Kl. N. Ser. 29: 186 pp., 35 tabs.

Tansley, A. G. 1946. Introduction to Plant Ecology, 2nd ed. Allen \& Unwin Ltd. London, $260 \mathrm{pp}$.

Tutin, T. G. et al. 1964-1972. Flora Europaea. University Press, Cambridge, Vol. 1 (464 pp.), Vol. 3 (370 pp.).

Tüxen, R. \& E. Oberdorfer. 1958. Die Pflanzenwelt Spaniens II. Veröff. geobot. Inst., Zürich 32: 328 pp.

Westhoff, V. \& A. J. Den Held. 1969. Plantengemeenschappen in Nederland. Thieme. Zutphen, $324 \mathrm{pp}$.

Wolff, $W$. 1968. The halophilous vegetation of the lagoons of Mesolonghi, Greece. Vegetatio 16: 95-134.

Zohary, M. 1962. Plant Life of Palestina. Ronald Press. New York, $262 \mathrm{pp}$.

Zohary, M. \& G. Orshan. 1966. An outline of the Geobotany of Crete. Israel J. Bot. 14 (Suppl.): 49 pp.

Accepted 4 January 1977 